\title{
CONTROL OF DIFFERENTIATION IN VOLVOX CARTERI
}

\author{
A model explaining pattern formation during embryogenesis \\ Manfred SUMPER \\ Institut für Biochemie, Genetik und Mikrobiologie, Lehrstuhl Biochemie 1, Universität Regensburg, Universitätsstraße 31, \\ 8400 Regensburg, FRG
}

Received 8 September 1979

\section{Introduction}

The green flagellate Volvox is a simple multicellular organism having only two kinds of cells, somatic and reproductive. The cells are arranged on the periphery of a spheroid. Asexual individuals of Volvox carteri are composed of $2000-4000$ somatic cells and about 16 large reproductive cells (gonidia), located in the posterior region of the spheroid. Mature asexual spheroids show a very regular spatial arrangement of the gonidia.

The development of all types of spheroids asexual, male and female - is through successive divisions of the asexual reproductive cells, the gonidia [1-3]. In the developing asexual embryo differentiation into somatic and reproductive cells is usually seen at the division from 32-64 cells. At this division 16 cells of the embryo undergo unequal cleavage, forming a small somatic and a large gonidial initial. While cell division ceases in the gonidial initials, the remaining cells (somatic initials) continue their synchronous divisions. At the termination of cell divisions, the many somatic cells form a hollow sphere with the gonidia conspicuously placed on the outer surface. After cleavage is complete, the embryo enters the process of inversion, turning itself inside-out. The gonidia remain in the same relative positions where they were formed during early embryogenesis. The young spheroid now enters a period of expansion. Formation of a gelatinous matrix of the colony begins and the cells become separated from one another.
Finally, the mature daughter colonies are released from the parent colony.

Its simple life cycle makes Volvox a promising material for the study of the mechanism controlling the orderly integration of cells during embryogenesis. In this paper I would like to propose a model to explain the following problems:

(1) What is the counting mechanism which tells a cell that the embryo is in the 2-, 4-, 8-, 16- or 32-celled stage?

(2) Why do only 16 cells out of the 32-celled embryo differentiate to gonidial initials?

(3) What is the mechanism controlling the relative positions of the gonidial initials within the developing embryo?

The model is mainly based on recent findings suggesting that specific recognition proteins and their sequential expression play a crucial role in developmental processes [4-13].

\section{Materials and methods}

Volvox carteri f. nagariensis, strain HK 10, used in this investigation was a gift from Professor L. Jaenicke, Cologne. The organism was grown in Volvox medium [14] according to published procedures [15]. 


\section{Results and discussion}

\subsection{The model}

Many aspects of the embryogenesis in Volvox can be explained by making the following three assumptions:

(i) The reproductive cell (gonidium) synthesizes membrane proteins which are able to mediate cell-cell contacts.

(ii) The expression of contact forming proteins is controlled in a hierarchical manner: a new set of contact forming protein species is produced only when the former set of contact forming protein species is quantitatively engaged in contact formation.

(iii) The presence (or absence) of a defined contact forming protein species signals gonidial differentiation.

The example given in table 1 and fig. 1 demonstrates how these processes differentiate the cells of the developing embryo with respect to their surface proteins. The uncleaved gonidium produces a first set of contact forming proteins (A-type contact, formed by membrane proteins $A$ and a). As soon as septum formation is initiated, these contact proteins of the cell membrane become trapped within the contact region simply by random diffusion and contact (complex-) formation (fig.1). By these processes the membrane area not involved in contact formation becomes cleared from all free contact proteins $(A, a)$. The absence of uncomplexed contact proteins is assumed to trigger the expression of a new set of contact proteins (denoted as type B), forming the contacts of the second division. Since it is reasonable to assume that the A-type contact area is not divided by the cleavage planes of the second division and since all divisions in Volvox continue to be parallel to the radial axes of the embryo, the cells of the 4-celled embryo will be arranged as shown in
Table 1

Differentiation in the developing embryo with respect to surface contact proteins

\begin{tabular}{ccc}
\hline Stage & $\begin{array}{l}\text { Types of contact } \\
\text { sites present in the } \\
\text { different cells }\end{array}$ & $\begin{array}{l}\text { Number } \\
\text { of cells }\end{array}$ \\
\hline $\begin{array}{c}\text { 2-celled } \\
\text { embryo }\end{array}$ & A & 2 \\
4-celled & A, B & 2 \\
embryo & B & 2 \\
8-celled & A, B, C & 2 \\
embryo & B, C & 2 \\
16-celled & C & 4 \\
embryo & A, B, C, D & 2 \\
& B, C, D & 2 \\
32-celled & C, D & 4 \\
embryo & A, B, C, D, E & 8 \\
& B, C, D, E & 2 \\
& C, D, E & 2 \\
& D, E & 4 \\
\hline
\end{tabular}

fig.1. Redrawing of the four cells in a more symmetrical configuration results in an arrangement typical of that seen by light microscopic observation: two cells touch while the other two fit into angles at base (fig.1). The four cells of the embryo are no longer identical with respect to their surface proteins: two cells contain both the contacts of type A and B, while the other two cells contain only contacts of type B.

Light microscopic observation reveals that the 8-celled embryo is shaped like a cup: The 4 cells at the posterior end of the embryo remain in close contact and while the 4 anterior cells may move anteriorly to form the typical hollow sphere, a pore, the phialopore, remains evident between the anterior cells. The model immediately explains this characteristic configuration: the contact sites established during septum formation in the third divison (C-type contacts) are shown in the schematic drawing of fig.1. Folding up this two-dimensional representation of the 8-celled embryo to a hollow sphere necessarily creates a pore

Fig.1. Differentiation in the developing embryo with respect to cell surface contact proteins. For details see text. Microphotos on the left show the 2-celled embryo, the 4-celled and the 8-celled embryo, respectively. 
Volume 107, number 1
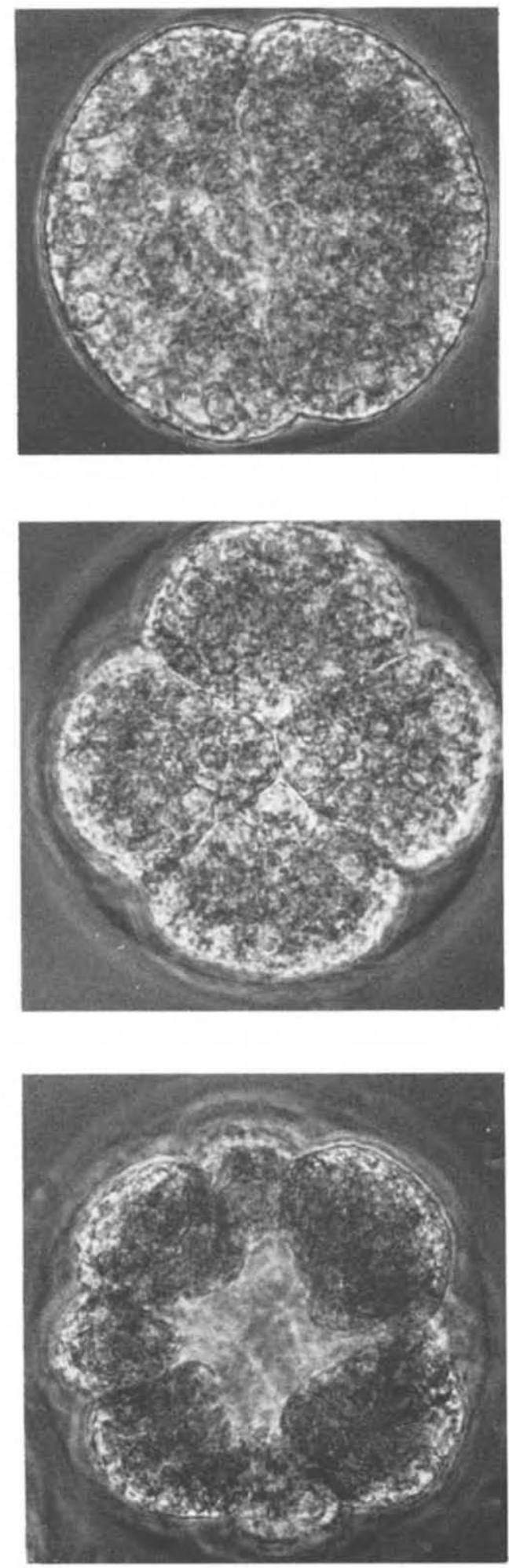

FEBS LETTERS
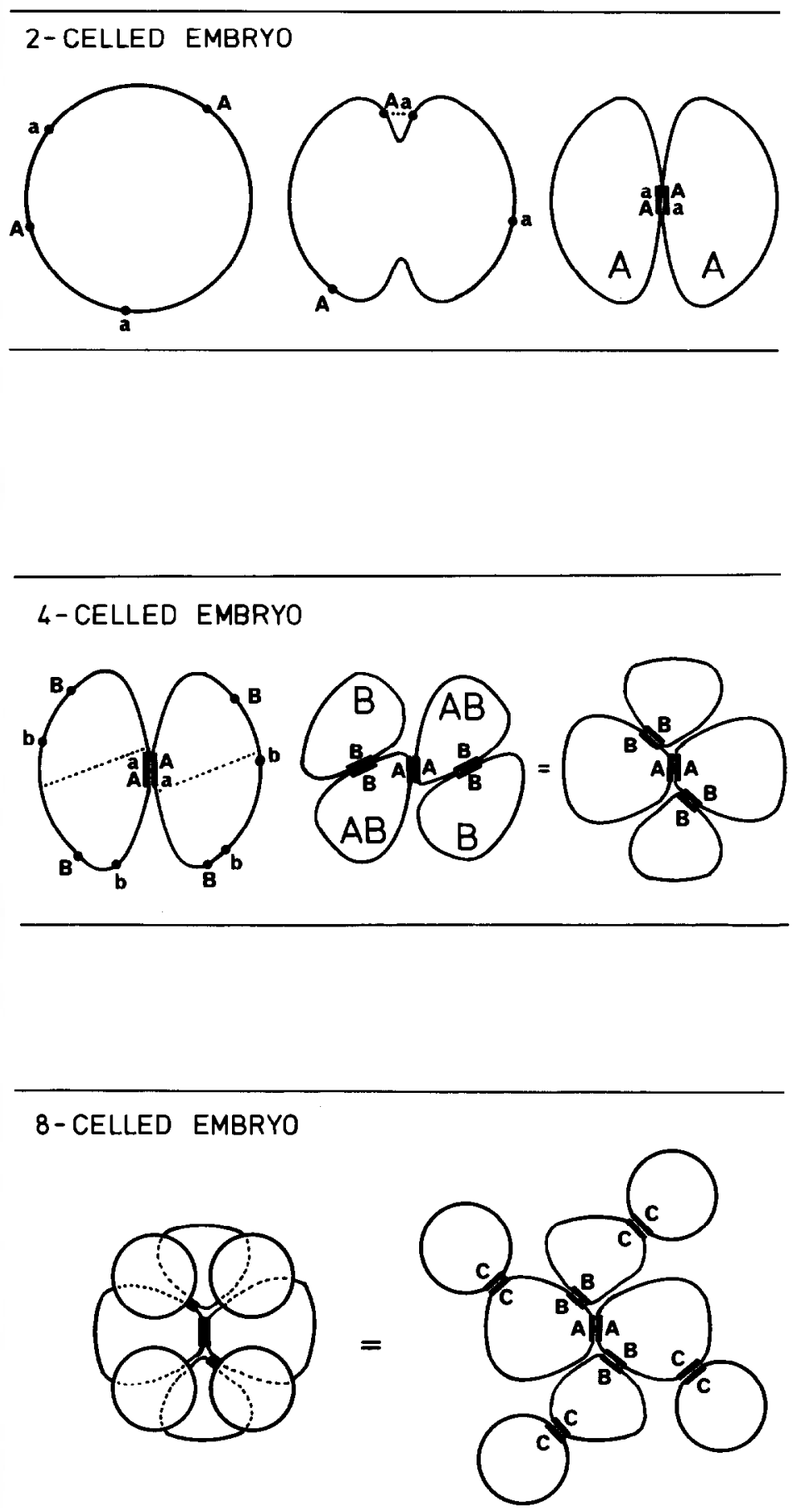

Fig.1. 


\section{6-CELLED EMBRYO}
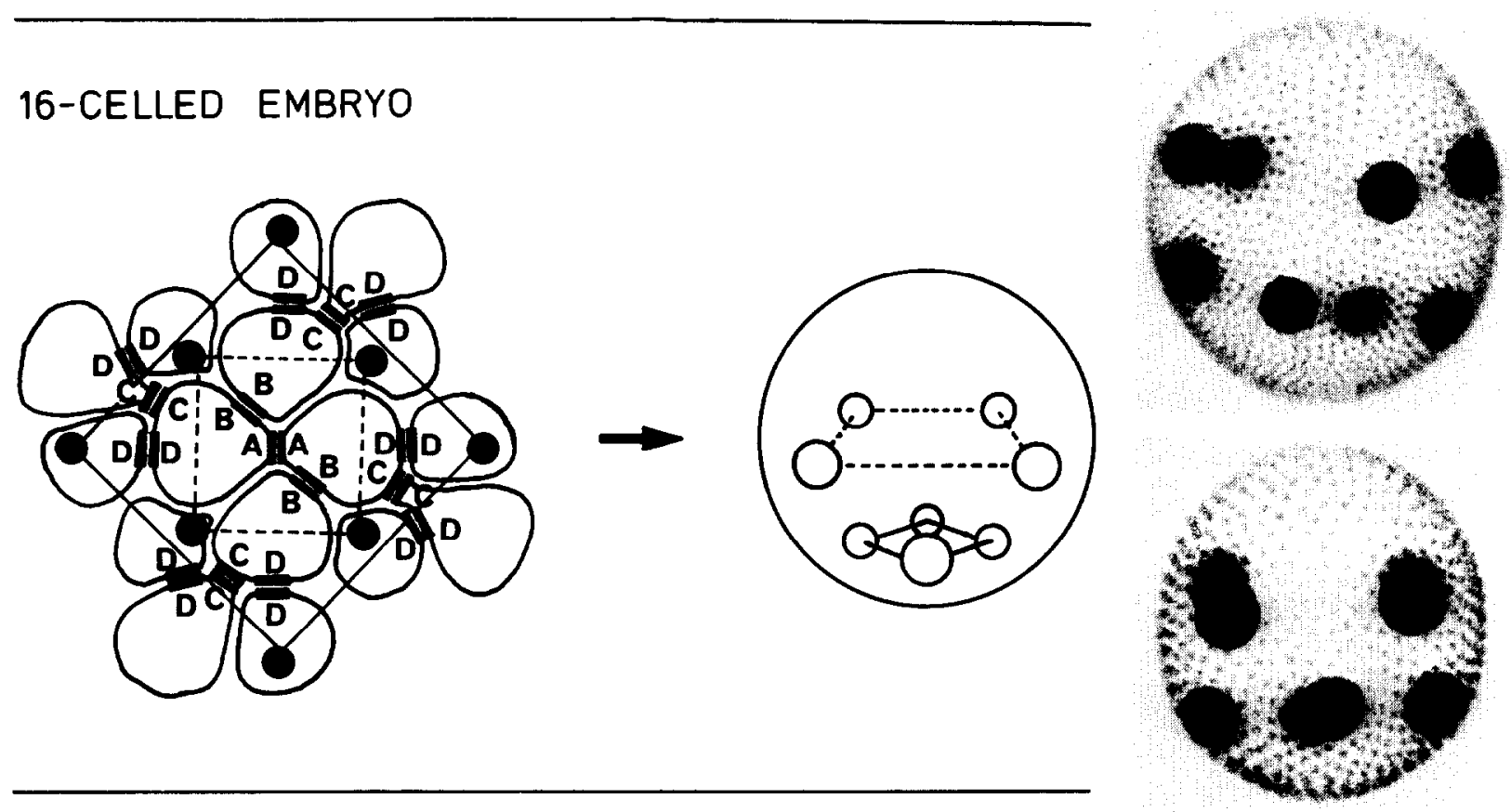

Fig.2. Positioning of cells having only one type of contact (D-type) within the 16-celled embryo. These are labeled with a black dot. For details see text. The photographs show Volvox spheroids containing eight gonidia.

at the anterior end because no contacts have been established between the 4 anterior cells. According to the model, the 8-celled embryo contains three different types of cells, namely 2 cells having A-, B- and C-contacts, another 2 cells having B- and C-contacts and finally 4 cells having only $C$-type contacts.

The arrangement of the cells and their contacts resulting from the fourth division is predicted by the model as shown in fig.2. Under certain environmental conditions, it is already at the division of the 16-celled embryo that the first morphological differentiation is apparent. At this division, 8 cells of the embryo undergo unequal cleavage, forming a small somatic initial and a large gonidial initial. It follows from the model that a maximum of 8 cells of the 16-celled embryo share the same set of contact sites, and thus a maximum of 8 cells are in the same state of biochemical differentiation. If this state (cells having only contacts of type $D$, see table 1 ) signals gonidial differentiation, the relative positions of the gonidia within the spheroid can easily be predicted. The cells having only D-type contacts are marked with filled circles in the two-dimensional representation of the 16-celled embryo in fig.2. By transforming this twodimensional pattern into a hollow sphere it follows that the 8 gonidial initials will be arranged in two parallel rectangles, tumed by $\mathbf{4 5}$ degrees against each other. In addition, one rectangle will be located near the equator and while the other rectangle will be located in the anterior half of the sphere (becoming the posterior half after inversion), the posterior half of the sphere will contain only somatic cells. This is exactly the pattern found in those Volvox spheroids containing only 8 gonidia.

\subsection{A more general version of the model}

Development of Volvox carteri spheroids containing only 8 gonidia occurs under less than optimal growth conditions. Under more favourable conditions Volvox spheroids usually contain 10-16 gonidia. Under optimal growth conditions, nearly all Volvox spheroids contain 16 gonidia. In this case, it is at the division of the 32-celled embryo that the first morphological differentiation is apparent. At this division 
16 cells undergo unequal cleavage, forming 16 gonidial initials. Obviously, the mechanism controlling gonidial differentiation allows for some flexibility, inducing gonidial differentiation either at the stage of the 16-celled embryo or at the stage of the 32-celled embryo.

In order to take this flexibility into consideration, a simplification is introduced into the model: If the contact proteins of a given type are engaged in more than only one stage of division, the observed flexibility can be explained by the model. In the example given in table 2 the assumption is made that the contact proteins of type $A$ are synthesized in variable amounts depending on growth conditions and, in particular, synthesized in amounts greater than being consumed by the first contact formation. In the first example of table 2 contact protein of type $A$ is only consumed after the third division. If all cells having only B-type contacts (or equivalently all cells lacking contacts of type A) are assumed to differentiate to gonidia, a spheroid develops having 8 gonidia arranged as shown
Table 2

Differentiation in the developing embryo, if a contact protein is engaged in more than only one stage of division

\begin{tabular}{crrr}
\hline Stage & $\begin{array}{l}\text { Types of contact sites present } \\
\text { in the different cells }\end{array}$ & $\begin{array}{l}\text { Number } \\
\text { of cells }\end{array}$ \\
\hline $\begin{array}{c}\text { 2-celled } \\
\text { embryo }\end{array}$ & A & & 2 \\
4-celled & A, A & & \\
embryo & A & & 2 \\
8-celled & A, A, A & & 2 \\
embryo & A, A & & 2 \\
16-celled & A, A, A, B & A, A, A, A & 2 \\
embryo & A, A, B & A, A, A & 2 \\
& A, B & A, A & 4 \\
32-celled & B & A & 8 \\
embryo & & A, A, A, A, B & 2 \\
& & A, A, A, B & 2 \\
& & A, A, B & 4 \\
& & A, B & 8 \\
B & 16 \\
\hline
\end{tabular}
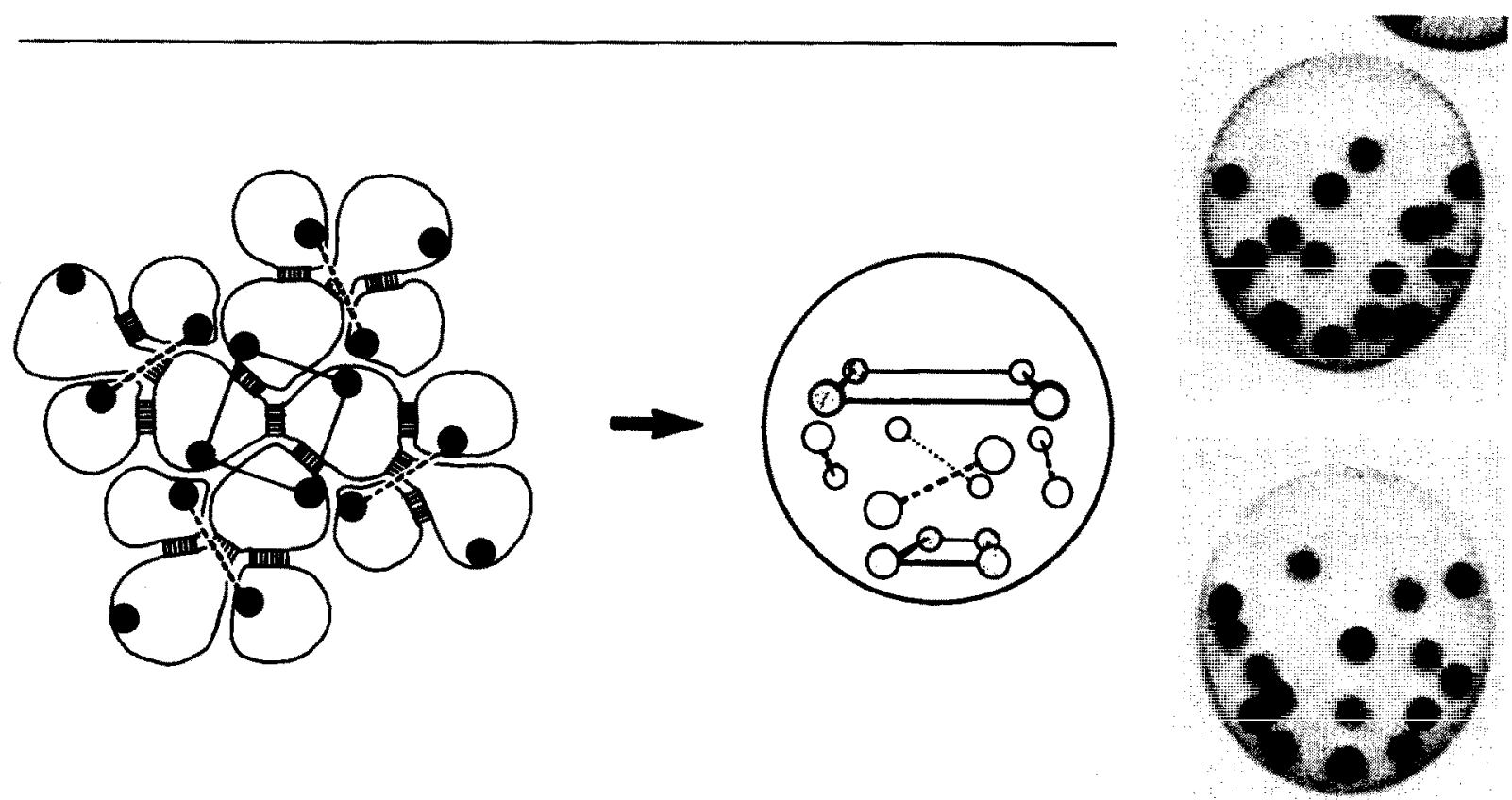

Fig.3. Estimation of the positioning of single-contact cells (only type B, see text for details), resulting from the cleavage of the 16-celled stage to the 32-celled embryo. The positions of these daughter cells are labeled with a black dot. These cells determine the positions of the 16 gonidia produced during the cleavage of the 32 -celled embryo. 
in fig.2. Under optimum conditions (synthesis of even higher amounts of contact proteins of type A) differ* entiation into gonidial initials is delayed until the 32-celled embryo is formed (the alternative example of table 2). The relative positions of the 16 cells having only B-type contacts (no A-type contacts) can be estimated from the schematic drawing of fig.3. By transforming again this two-dimensional pattern into a hollow sphere it follows that the 16 gonidia should be arranged in two parallel rectangles and a zig-zag like band being enclosed by the rectangles as shown schematically in fig.3. The anterior third of the sphere should contain no gonidia. This is exactly the pattern found in Volvox spheroids containing 16 gonidia (fig.3).

In the accompanying paper [16] we present some experimental results supporting this model: We show that certain chemical modifications of the membrane surface during embryogenesis strongly disturb the control of gonidial differentiation without affecting the viability of the embryo.

\section{References}

[1] Kochert, G. J. (1968) J. Protozool. 15, 438-452.

[2] Starr, R. C. (1970) Dev. Biol. Supp. 4, 59-100.

[3] Kochert, G. (1975) in: Developmental Biology of Reproduction (Markert, C. L. and Papaconstantinon, J. eds) pp. 55-90.
[4] Boyse, E, and Old, L. (1969) Annu. Rev. Genet. 2, 269-290.

[5] Moscona, A. A. (1974) in: The Cell Surface in Development (Moscona, A. A. ed) pp. 67-100, Wiley and Sons, New York.

[6] Edelman, G. M., Spear, P. G., Rutishauser, U. and Yahara, I. (1974) in: The Cell Surface in Development (Moscona, A. A. ed) pp. 141-164, Wiley and Sons, New York.

[7] Hausman, R. E. and Moscona, A. A. (1975) Proc. Natl. Acad. Sci. USA 72, 916-920.

[8] McMahon, D., Hoffman, S., Fry, W. and West, C. (1975) in: Developmental Biology (McMahon, D. and Fox, C. F. eds) vol. 2, pp. 60-75, W. A. Benjamin, London.

[9] Rutishauser, U., Thiery, J.-P., Brackenbury, R., Sela, B.-A. and Edelman, G. M. (1976) Proc. Natl. Acad. Sci. USA $73,577-581$.

[10] Hausman, R. E. and Moscona, A. A. (1976) Proc. Natl. Acad. Sci. USA 73, 3594-3598.

[11] MoClay, D. R., Chambers, A. F. and Warren, R. H. (1977) Dev. Biol. 56, 343-355.

[12] Müller, K. and Gerisch, G. (1978) Nature 274,445-449.

[13] Noll, H., Matranga, V., Cascino, D. and Vitorelli (1979) Proc. Natl. Acad. Sci. USA 76, 288-292.

[14] Provasoli, L. and Pintner, I. J. (1959) in: The Ecology of Algae (Tyron, C. A. and Hartman, R. T. eds) spec. publ. no. 2, pp. 84-96, Pymatuning Lab. Field Biol., Univ. Pittsburg.

[15] Starr, R. C. and Jaenicke, L. (1974) Proc. Natl. Acad. Sci. USA 71, 1050-1054.

[16] Wenzl, S. and Sumper, M. (1979) FEBS Lett. 107, $247-249$. 